\title{
Reforming Energy Law at a National Level
}

\author{
Professor Raphael J Heffron \\ Centre for Energy, Petroleum, Mineral Law \& Policy, \\ University of Dundee \\ Nethergate, Dundee DD1 4HN, UK \\ r.heffron@dundee.ac.uk
}

\begin{abstract}
This short chapter provides a brief introduction to the key steps of how to reform energy law. Initially, there is a need to understand energy law and its origin and its relationship with other disciplines through the energy lifecycle. Then the article details the drivers of energy law, four recent positive developments, and finally the seven principles of energy law. Finally, there is a discussion on legal certainty and how it is developed through the application of the energy law principles and the recent new initiatives. As legal certainty will provide the platform for long-term change in energy sector through ensuring there is investment.
\end{abstract}

Keywords- energy law; energy life-cycle; evolution of energy law; drivers of energy law; principles of energy law

\section{INTRODUCTION}

Energy law is one of the most exciting and growing areas of law at the moment. There is a realisation worldwide of the importance of the energy sector in the global economy and also national and local economies. Consequently the law that governs the energy sector is instrumental in ensuring it functions as an efficient, environmentally sustainable and reliable sector of the economy.

Nation states across the world continue to seek economic growth and a functioning energy sector is a vital component to this. The energy sector can contribute revenue to an economy in the form of taxation of energy extraction and production. Further an efficient energy sector can ensure benefits to other sectors of the economy in particular to industry and it is now seen as a key part of national industrial strategies and policies. In addition, there are benefits to ensuring increased energy access to the public and that energy prices do not impact in a significant way on an individual's disposable income, i.e. meaning they can save and consume other goods.

Energy law also plays a significant role in the future and in particular when there are 2030, 2040 and 2050 energy, environment and climate plans. In order to achieve, for example, 2030 climate and energy targets, the law has to be formulated, passed and implemented to achieve that 2030 target. This is because energy infrastructure takes not only time to plan, raise finance for, and to build, but also there are significant planning and environmental hurdles to overcome. And these all feed into the second point, it is at a national level that the law can drive the energy transition. A national government can set a policy agenda and ensure law provides the structures, the incentives, and the pathways for an energy transition to occur.
It is therefore clear that energy law has a significant role to play in society. This short chapter in this conference proceedings highlights the relationship between mining and energy law. It then focuses on the key drivers of energy law, i.e. what are the key issues that are the cause of change to energy law. Then in section three, there are four key recent developments in energy law that are briefly introduced and analysed and these are: environmental impact assessments; the social license to operate; the energy finance reserve obligation; and extractive industries transparency initiative. In section four, the recently published principles of energy law but a group of academics from across the world are detailed. Finally, the conclusion highlights the need for longterm certainty in energy law so that investment can occur.

\section{MINING LAW AND ENERGY LAW}

Mining law is just one aspect of energy law and it is important to view how it fits into energy law. Energy law can be defined as "... the regulation of energy related rights and duties of various stakeholders over energy resources over the energy life-cycle."[1] The energy life-cycle referred to consists of five major stages as identified below in Figure 1.

Figure 1: THE ENERGY LIFE-CYCLE[1]
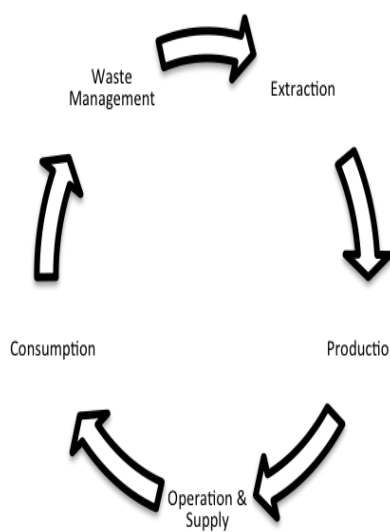

Mining (or exploration and extraction) is the first stage of the energy life-cycle. In terms of thinking about the energy sector in its entirety and what are the key drivers, generally, energy law scholarship holds that overtime there are key five stages or drivers[2]. These drivers are represented below in Figure 2 and they are: Safety, Security, Economic, Infrastructure and Justice. These five drivers are present at any one time but one or two may be the principal driver. 
Figure 2: The Five Stages (DRIVERS) OF THE EVOLUTION OF ENERGY LAW

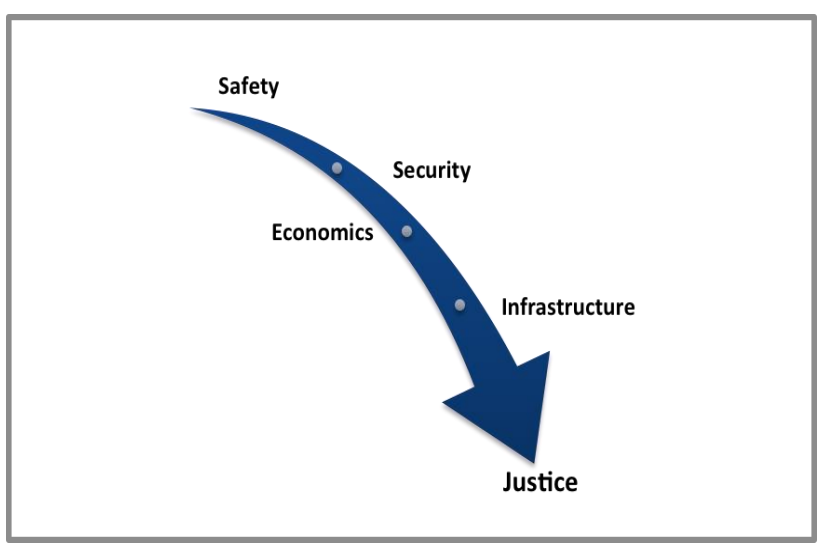

\section{RECENT POSITIVE DEVELOPMENTS IN ENERGY LAW}

The following are four key areas for which requirements to disclose information is and should be on corporations. There is an imbalance between how energy firms and the other actor groups engage with each other on mining issues; these mining companies have far more access to expertise and it should be their obligation to ensure national governments, regional/local governments, and local communities have access to the requisite information. The following are four mechanisms that are and should be coming into effect worldwide[3].

\section{A. Environmental Impact Assessments (EIAs)}

The aim of an Environmental Impact Assessment (EIA) is for international, national and local communities to achieve a balance between development and the environment. There are many other methods and strategies for balancing development and the environment but an EIA is a formalised process that has had international and national consensus on its development over time. This paper does not aim to go into particular depth on EIAs[4] as the arguments presented here focus on what the EIAs can achieve. Overall, the EIA process has to be seen as a success from a global international perspective. In essence, it promotes the cosmopolitan philosophical ideal that people are all world citizens[5]. In this context the EIA process has placed certain limitations on development and ensured that development that does occur is achieved with environmental protection as a core aim from the beginning of the process. For any country, with a stated ambition of developing a low-carbon economy and plans to develop policies on climate change mitigation and protection of the environment, the EIA process should be a welcome addition to these plans. Already at international level the EIA is promoted for use in nearly all projects funded by international development agencies such as the World Bank, the OECD, and the UNEP. This area of law is still developing fast and is set for further reform to a degree in 2017 when it comes more inter-related to climate change.

\section{B. Social Licence to Operate (SLO)}

The SLO is a fast emerging principle in energy law and in particular developed around the mining law and policy community[6]. However, it is permeating through the rest of the energy sector and even other parts of the economy. There are a number of papers which explore the origin of the SLO and its use in the mining sector and it is certain that in the future the vast majority of the energy infrastructure will need an SLO before beginning operation[7].

\section{Energy Financial Reserve Obligation (EFRO)}

This is a general term for the obligation that companies should have when operating energy infrastructure. In particular, the EFRO applies in terms of companies with waste obligations - or indeed the companies that should have waste obligations. These can also be referred to as clean-up obligations and environmental bonds, and the nuclear energy industry contributes to waste management funds immediately from the point of operation whereas in the coal industry, the operator only has to have the financial reserve capacity to do so[8]. Indeed this has become a major issue and there is a multitude of reports focusing on it in relation to the operation of coal assets in Australia and US[9]. For example, in the US, under the Federal Surface Mining Control and Reclamation Act (SMCRA)[10], energy companies are required to remediate the lands where mining activity has occurred. However, many companies were allowed to selfbond and therefore when they went bankrupt there was still no finance available for meeting reclamation obligations[11].

\section{Extractive Industries Transparency Initiative (EITI) [12]}

There needs to be more active promotion of the EITI across the world. The EITI is an international agreement whereby countries record how much companies pay their governments for the rights to extract energy resources. It now covers 'beneficial ownership disclosure, contract transparency, the integration of the EITI into government systems and transparency in commodity trading. The focus of EITI Reports has moved from compiling data to building systems for open data and making recommendations for reforms to improve the extractive sector governance more generally.'[13] The EITI began really as a response to the 'resource curse' and it has continued to gain momentum with 56 countries now part of it. The initiative began in 2002, and the World Bank endorsed and initially funded it. The EITI has however been under revision from its inception until this year with the production of the EITI Standard 2016 which is the new system in place for achieving disclosure.

\section{FORMULATING ENERGY LAW FOR THE TRANSITION}

In thinking of how to achieve for example, 2030 climate and energy goals, a country has to establish new law on how to achieve this energy transition. There is no common solution as countries have control over their own energy resources and they have different geographies, culture and socio-economic characteristics.

Nevertheless, there are now accepted guiding principles to follow for the development and application of energy law. Such guiding principles can be a force of change, for example, we can witness worldwide the example of one of the most established environmental principles, i.e. the polluter pays principle. In this context, these principles of 
energy law can "act as a guide to policymakers, academics, lawyers, judges and arbitrators when adjudicating, enforcing, making or formulating documentation, laws, regulations, judgments, etc on energy law".[14]

Energy law is stated as having seven guiding principles and these are stated below in Table 1.

TABLE 1: PRINCIPLES OF ENERGY LAW[15]

\begin{tabular}{|c|c|}
\hline \multicolumn{2}{|r|}{ Principles of Energy Law } \\
\hline 1. & $\begin{array}{l}\text { The Principle of Natural Resource Sovereignty } \\
\text { - The right of a state to use their natural resources in } \\
\text { their own national interest }\end{array}$ \\
\hline 2. & $\begin{array}{l}\text { The Principle of Access to Modern Energy Services } \\
\text { - Access to energy should be available to all citizens of a } \\
\text { nation }\end{array}$ \\
\hline 3. & $\begin{array}{l}\text { The Principle of Energy Justice } \\
\text { - The application of human rights across the energy } \\
\text { system }\end{array}$ \\
\hline 4. & $\begin{array}{l}\text { The Principle of Prudent, Rational and Sustainable Use } \\
\text { of Natural Resources } \\
\text { - Natural resources should achieve a balance between } \\
\text { economic development and environmental concerns }\end{array}$ \\
\hline & $\begin{array}{l}\text { The Principle of the Protection of the Environment, } \\
\text { Human Health \& Combatting Climate Change } \\
\text { - The use of energy and natural resources should be } \\
\text { comply with the triple objective of protecting the } \\
\text { environment, public health and climate change } \\
\text { mitigation }\end{array}$ \\
\hline & $\begin{array}{l}\text { Energy Security and Reliability Principle } \\
\text { - There should be a secure supply of energy that should } \\
\text { also be reliable }\end{array}$ \\
\hline 7. & $\begin{array}{l}\text { Principle of Resilience } \\
\text { - The different energy activities in the energy system } \\
\text { should be resilient so they can plan, recover, and adapt } \\
\text { to adverse events }\end{array}$ \\
\hline
\end{tabular}

\section{CONCLUSION: ENSURING LONG-TERM CHANGE THROUGH LEGAL CERTAINTY}

The importance of the long-term focus of the energy law principles highlighted above in the previous section cannot be understated. These principles when with the long-term ambition for the energy sector will provide legal certainty in the energy sector. This will result in a reduction in the risk profile of an energy infrastructure project and thus borrowing costs will reduce.

There is one final part of the energy transition that a country needs to consider and legal thinking has a key role to play in this. In its energy sector and its society, countries and their respective governments have to ensure that the transition of its energy sector is a 'just' transition. Decisionmaking has to be transparent, politicians accountable and the public have to see justice in the processes and outcomes of these decisions.

Recent literature details key issues around the 'just transition' to a low-carbon economy[16]. One of the key aspects in this context is also about ensuring the transition of all aspects of the energy sector. New expertise needs to be developed so as to strengthen the environment and energy regulators. Also, the existing energy labour force need to have access to re-training and new educational opportunities so they can adjust and be part of the energy transition. These latter issues are also enshrined in the energy law principle (see Table 1) of resilience. And crucially it involves public participation in the transition, and ensures more socially acceptable outcomes (even if perhaps it were to be viewed as a more costly option than new fossil fuel infrastructure).

Overall, policy-makers have to ensure that investors see a long-term vision in the energy sector that is enabled by supporting legislation and so this provides legal certainty as to the Government's aims. Achieving this, while difficult has the benefit of providing a platform for securing investor confidence as they then can invest due to the risk reducing around new energy infrastructure projects. Indeed, new energy law that is based on the guiding principles will provide this clarity and certainty for investors and also the public, two of the key stakeholders in a national energy sector.

The formulation and application of revised and/or new energy law can set a start date on how a country could achieve its energy transition by 2030, 2040 and 2050 goals. This can result in a positive societal experience and one that has far more benefits and is more 'just' than a retention of the current status quo for all participants in a national energy sector.

\section{ACKNOWLEDGMENT}

This is a culmination of a different work from Raphael Heffron. All errors or omissions are the authors alone. The author thanks all publishers for any reprodiced tables, figures and wording for this chapter. All queries please contact the author on the email address at the start of the chapter.

\section{REFERENCES}

[1] P. 5, Heffron, R. J. and Talus. K. 2016. The Evolution of Energy Law and Energy Jurisprudence: Insights for Energy Analysts and Researchers. Energy Research and Social Science, 19, 1-10.

[2] Heffron and Talus, 2016.

[3] The first three examples here are from the paper by the author: Heffron, R. J. 2016. The Global Future of Energy Law. International Energy Law Review, 7, 290- 295. Thanks is expressed to the publisher: International Energy Law Review, Sweet \& Maxwell (Thomson Reuters).

[4] EIAs do not feature in a significant manner in many environmental law texts either, despite being the cause of many legal cases each year - however, there are a number of interdisciplinary texts on the subject. There are a number of texts specifically on EIAs. The key book on EIAs is Environmental Impact Assessment by Tromans (2012) and though it has a UK focus, it contains a very good approach from an EU law perspective: S. Tromans, Environmental Impact Assessment, 2nd edn (West Sussex, UK: Bloomsbury Professional Ltd, 2012). A second key law text on EIAs (but with a focus on Ireland) is: A. Ryall, Effective Judicial Protection and the Environmental Impact Assessment Directive in Ireland, (Oxford, UK: Hart Publishing, 2009).

[5] Cosmopolitan philosophy is the belief in that we are all 'world citizens'. Cosmopolitanism has existed in some form since the ancient Greeks. The first philosopher in the West to give a perfectly explicit expression of cosmopolitanism was the Socratically-inspired Cynic Diogenes in the fourth century BC - it is said that when asked where he came from, he replied 'I am a citizen of the world' (Diogenes Laertius VI 63): Stanford Encyclopaedia of Philosophy, 2013 (Revised), 'Cosmopolitanism', available at: http://plato.stanford.edu (last accessed May 2016).

[6] For more see: On Common Ground Consultants Inc. 2014. What is the Social License? Available at: http://socialicense.com/definition.html (last accessed June 2016).

[7] See the discussion in both the following: (1) Prno, J. and Slocombe, D. S. 2012. Exploring the origins of 'social license to operate' in the mining sector: Perspectives from governance and sustainability theories. Resources Policy, Vol. 37 (3), 346-357; and (2) The 
Guardian (Morrison, J.). 2014. Business and society: defining the 'social licence'. 29 September 2014. Available at: https://www.theguardian.com/sustainable-

business/2014/sep/29/social-licence-operate-shell-bp-businessleaders (last accessed June 2016).

[8] Dondo, S. J. 2014. 'Financial Assurance for Mine Closure: A Regulatory Perspective from the Argentine Context'. CSRM Occasional Paper, Centre for Social Responsibility in Mining (CSRM), Sustainable Minerals Institute (SMI), University of Queensland.

[9] See for example the following: (1) International Business Times (Gallucci, M.). 2016. When A Coal Company Goes Bankrupt, Who Is Left To Clean Up The Mess? (14 January 2016). Available at: http://www.ibtimes.com/when-coal-company-goes-bankrupt-wholeft-clean-mess-2264097 (last accessed June 2016); (2) The Guardian (Robertson, J.), 2016. Coal giants abandon unprofitable mines, leaving rehabilitation under threat .(28 January 2016).

Available

at:

https://www.theguardian.com/environment/2016/jan/29/coal-giantsabandon-unprofitable-mines-leaving-rehabilitation-under-threat (las accessed June 2016); and (3) Miller, C. G. 2005. Financial Assurance for Mine Closure and Reclamation. (International Council on Mining \& Metals). Available at: https://www.icmm.com/document/282 (last accessed June 2016).

[10] Federal Surface Mining Control and Reclamation Act (SMCRA). Available at: http://www.osmre.gov//rg.shtm (last accessed June 2016). And for Australian rules see: Financial assurance under the Environmental Protection Act 1994. Queensland Government Department of Environment and Heritage Protection. Available at: http://www.ehp.qld.gov.au/assets/documents/regulation/era-glfinancial-assurance-ep-act.pdf (last accessed December 2016).
[11] See: (1) Bloomberg (Biesheuval, T., Riseborough, J. and De Sousa, A.), 2015. Why Bankruptcy Might Be the Mining Industry's Last Best Hope (3 December 2015). Available at: http://www.bloomberg.com/news/articles/2015-12-03/whybankruptcy-might-be-the-mining-industry-s-last-best-hope (last accessed December 2016); and (2) ABC Australia News (Lannin, S.). 2015. China economist warns major miners may collapse in $2016 \quad$ (18 December 2015) Available at: http://www.abc.net.au/news/2015-12-17/china-economist-warnsthat-iron-ore-miners-will-collapse/7037802 (last accessed December 2016).

[12] Extractive Industries Transparency Initiative. 2016. Available at: https://eiti.org/ (last accessed December 2016).

[13] EITI. 2016.

[14] P.48. Heffron, R. J., Ronne, A., Bradbrook, A., Tomain, J. P. and Talus, K. 2018. A Treatise for Energy Law. Journal of World Energy Law \& Business, 11 (1), 34-48.

[15] P.40. Heffron, R. J., et al. 2018.

[16] Heffron R. J. and McCauley, D. 2018. What is the 'Just Transition'? Geoforum, 88, 74-77. 